\title{
The levels of hs-CRP in patients with coronary heart disease
}

\author{
R.L. Lefrandt
}

\begin{abstract}
Abstrak
Aterosklerosis sebagai penyebab terjadinya PJK merupakan proses multifaktorial karena banyak sekali faktor-faktor yang menyebabkannya dengan mekanisme yang saling terkait. Saat ini proses aterosklerosis dianggap sebagai proses inflamasi. Inflamasi terbukti berperan penting pada inisiasi, progresi maupun destabilisasi plak aterosklerosis. High sensitivity C-reactive protein (hs$C R P)$ merupakan salah satu petanda inflamasi yang penting pada penyakit jantung koroner (PJK) yang berhubungan dengan tingkat keparahan aterosklerosis, iskemi miokardium dan nekrosis miokardium. Tujuan penelitian ini adalah untuk mengetahui dan membandingkan kadar hs-CRP pada pasien sindroma koroner akut (SKA), PJK kronik dan bukan PJK, serta untuk mengetahui apakah terdapat hubungan antara kadar hs-CRP dengan kadar enzim CKMB pada pasien infark miokard akut (IMA). Penelitian bersifat observasional deskriptif dan analitik dengan pendekatan potong lintang. Dilakukan pemeriksaan kadar hs-CRP dengan metode chemiluminescent pada 21 pasien SKA, 20 pasien PJK kronik dan 20 bukan PJK. Didapatkan kadar hs-CRP rerata pada pasien SKA, PJK kronik dan bukan PJK sebesar 8,40 (SD 5,53) mg/l, 2,81 (SD 2,09) mg/l dan 1,07 (SD 0,81) mg/l. Analisis statistik didapatkan perbedaan kadar hs-CRP yang bermakna antara pasien SKA, PJK kronik dan bukan PJK (p 0,000). Kadar hs-CRP mempunyai korelasi positif yang bermakna dengan kadar enzim CKMB pada pasien IMA (p 0,004). Sebagai kesimpulan, kadar hsCRP pada pasien SKA secara bermakna lebih tinggi dibanding PJK kronik dan bukan PJK. Terdapat hubungan yang bermakna antara peningkatan kadar hs-CRP dengan peningkatan kadar enzim CKMB. (Med J Indones 2004; 13: 102-6)
\end{abstract}

\begin{abstract}
Coronary heart disease (CHD) due to atherosclerosis is a multifactorial process with multiple interdependent factors. At present time, atherosclerosis is considered to be an inflammatory process. It has been proven that inflammation plays a mayor role in the initiation, progression as well as the destabilitation of the atherosclerosis plaque. High sensitivity $C$-reactive protein $(h s-C R P)$ is one of the most important inflammatory marker in CHD and directly related to the extent and severity of atherosclerosis, extent of myocardial ischemia and myocardial necrosis. The purpose of this study is to determine hs-CRP levels in patients with acute coronary syndrome (ACS), chronic CHD and non CHD. And, to determine the correlation between hs-CRP levels and CKMB enzyme level in patients with acute myocardial infarction (AMI). This is a descriptive observational analytic study with cross sectional design. hs-CRP levels were measured by using chemiluminescent method on 21 ACS patients, 20 chronic CHD patients and 20 non CHD patients. The mean hsCRP level in ACS, chronic CHD and non CHD patients were respectively 8.40 (SD 5.53) $\mathrm{mg} / \mathrm{l}, 2.81$ (SD 2.09) $\mathrm{mg} / \mathrm{l}$ and 1.07 (SD 0.81$)$ $\mathrm{mg} / \mathrm{l}$. A statistically significant difference in hs-CRP level was found between ACS, chronic CHD and non CHD ( $p=0.000)$. A positive correlation was found between hs-CRP level and CKMB enzyme level in AMI patients ( $p=0.004)$. In conclusion hs-CRP level is consistently higher in patients with ACS compared to patients with chronic CHD and non CHD. A positive correlation was found between the increased level of hs-CRP and CKMB enzyme level. (Med J Indones 2004; 13: 102-6)
\end{abstract}

Keywords: atherosclerosis, inflammation, $h s-C R P, C H D$

According to the current concept, atherosclerosis process is more considered as inflammation process rather than only the consequence of fat accumulation at the vessel walls. ${ }^{1,2}$ The finding of $\mathrm{T}$ lymphocytes, monocytes, macrophages and mast cells in atherosclerotic

Cardiology Division, Internal Medicine Department, Faculty of Medicine Sam Ratulangi University/Manado General Hospital, Manado, Indonesia lesions and secretion of cytokines obviously showed the evidence of inflammation element in atherosclerotis process. ${ }^{2-5}$ Unstable atherosclerotic plaque that later became rupture and caused ACS was also due to the existence of inflammation response in the form of activated $\mathrm{T}$ lymphocytes, increase CRP and other inflammation markers. ${ }^{2,5,6}$ Van der Wall et $\mathrm{al}^{7}$ reported that there was inflammation cells quantity increase (macrophages, $\mathrm{T}$ lymphocytes, and mast cells) at rupture plaque. Liuzzo et $\mathrm{al}^{8}$ reported that hs-CRP 
level and serum amyloid A protein (SAA) in unstable angina pectoris (UAP) patients was higher than in stable angina pectoris patients and the height of hsCRP level served as poor indicator of patient prognosis. de Beer et $\mathrm{al}^{9}$ said that there was a significant correlation between hs-CRP level and CKMB enzyme level in AMI patients.

Age, sex, blood lipid levels, hypertension and diabetes influence on hs-CRP level was not clear. According to Yeh and Willerson, ${ }^{10}$ age and sex did not affect hsCRP levels. Haverkate et $\mathrm{al}^{11}$ said that age and triglycerides level affect hs-CRP level, but blood cholesterol level, hypertension and diabetes did not affect hs-CRP level, whereas according Rifai $^{12}$ and Pierson et al, ${ }^{13}$ hypertension and diabetes did affect hs-CRP levels. According to Ridker,${ }^{14}$ blood lipid levels did not affect hs-CRP levels. Obesity (measured by BMI) can increase hs-CRP level, but its mechanism was not clear yet. One of the possibilities was because adipose tissue can produce proinflammatory cytokines. Smoking can increase hsCRP levels, IL-6 and ICAM-1, while stop smoking can decrease the inflammation markers levels. ${ }^{12,15}$

Statin and aspirin as antiinflammation were obviously effective in both primary and secondary CHD prevention. ${ }^{16,17}$

\section{METHODS}

This study was carried out from May to September 2003 in Cardiology Division Manado General Hospital. The study population comprised of ACS, chronic CHD and non CHD patients. Inclusion criteria were ACS patients (UAP and AMI with onset 4-24 hours from start of chest pain and did not obtain thrombolysis therapy yet), chronic CHD and non CHD. Exclusion criteria were patients suffering from infection disease, arthritis, renal failure, malignancy, liver disease, rheumatic fever, blood diseases such as leukaemia, patients who received transplantation and pregnant, patients who receving statin drugs, NSAIDs, antibiotics, corticosteroids, immunosuppresive therapy and estrogen. hs-CRP level examination was carried out by using chemiluminescent (Immulite) method with normal value $<1,1 \mathrm{mg} / \mathrm{l}$. Data analysis used was variance analysis (Anova) to find out the hs-CRP levels difference in ACS, chronic CHD and non CHD patients. If the result was significant the analysis was continued with least significant difference (LSD) test. The $t$ independent test was used to find out the hs-CRP levels difference in UAP and AMI patients. The regression analysis was used to find out the relationship between hs-CRP level and CKMB enzyme level in AMI patients.

\section{RESULTS}

During the study 61 patients were found, consisting of 21 ACS patients, 20 chronic CHD patients and 20 non CHD patients. The characteristics data of the three patient groups can be seen in Tables 1 and 2. No significant difference of age, sex, BMI, hypertension, smoking, total cholesterol level, LDL, HDL and triglycerides between ACS, chronic CHD, non CHD patients and between UAP and AMI patients.

Table 1. Characteristics data of ACS, chronic CHD and non CHD patients

\begin{tabular}{lcccc}
\hline & ACS & Chronic CHD & Non CHD & p value \\
& {$[\mathrm{n}=21]$} & {$[\mathrm{n}=20]$} & $60,25(6,74)$ & 0,785 \\
\hline Age [yrs] & $61,48(10,26)$ & $61,95(6,15)$ & $14 / 6$ & 0,993 \\
Sex [ J/\%] & $15 / 6$ & $14 / 6$ & $25,86(2,66)$ & 0,796 \\
BMI [kg/m2] & $26,59(3,32)$ & $26,32(4,24)$ & 75 & 0,699 \\
Hypertension[\%] & 76,2 & 85 & & 0,960 \\
Smoking [\%] & & & 40 & \\
- Active* & 33,3 & 30 & 30 & 0,288 \\
- Past “ & 38,1 & 40 & 30 & 0,236 \\
- Never & 28,6 & 30 & $200,30(35,94)$ & 0,179 \\
Total Cholest & $214,24(30,94)$ & $219,55(49,49)$ & $127,66(37.57)$ & 0,757 \\
LDL & $144,00(29,65)$ & $149,51(54,81)$ & $45,50(8,31)$ & \\
HDL & $41,24(7,28)$ & $41,35(8,97)$ & $135,70(38,48)$ & \\
Triglycerides & $145,00(41,93)$ & $143,45(46,35)$ & & \\
\hline
\end{tabular}

( ) : standard deviation

* Active : still smoking up to 1 month ago, ${ }^{11}$

"Past : stopped smoking longer than 1 month ago ${ }^{11}$ 
Table 2. Characteristics data of ACS patients (UAP and AMI)

\begin{tabular}{lccc}
\hline & UAP $[\mathrm{n}=10]$ & AMI $[\mathrm{n}=11]$ & $\mathrm{p}$ value \\
\hline Age $[\mathrm{yrs}]$ & $60,90(8,47)$ & $62,00(12,05)$ & 0,813 \\
Sex $[\hat{0} / \mathrm{q}]$ & $7 / 3$ & $8 / 3$ & 0,633 \\
BMI $[\mathrm{kg} / \mathrm{m} 2]$ & $27,01(4,19)$ & $26,20(2,43)$ & 0,590 \\
Hypertension $[\%]$ & 80 & 72,7 & 0,550 \\
Smoking $(\%)$ & & & 0,953 \\
- Active* & 30 & 36,4 & \\
- Past “ & 40 & 36,4 & \\
- Never & 30 & 27,2 & \\
Total Cholest & $218,30(32,67)$ & $210,55(30,38)$ & 0,580 \\
LDL & $148,88(32,45)$ & $139,56(27,65)$ & 0,486 \\
HDL & $40,00(7,76)$ & $42,36(6,99)$ & 0,472 \\
Triglycerides & $147,10(44,44)$ & $143,09(41,61)$ & 0,833 \\
\hline
\end{tabular}

The mean hs-CRP level in ACS, chronic CHD and non CHD patients were respectively 8.40 (SD 5.53) $\mathrm{mg} / \mathrm{l}, 2.81$ (SD 2.09) $\mathrm{mg} / \mathrm{l}$ and 1.07 (SD 0.81) $\mathrm{mg} / \mathrm{l}$. A statistically difference in hs-CRP level was found between ACS, chronic CHD and non CHD ( $\mathrm{p}=0.000)$. When ACS was compared to chronic CHD, a statistically significant difference in hs-CRP level was found $(\mathrm{p}=0.000)$. No statistically significant difference in hs-CRP level was found when comparing chronic CHD and non CHD ( $p=0.363)$ (Fiqure 1). Mean hs-CRP level in UAP and AMI patients were respectively 4.90 (SD 2.21) $\mathrm{mg} / \mathrm{l}$ and 11.57 (SD 5.78) $\mathrm{mg} / \mathrm{l}$. Statistic analysis result with $\mathrm{t}$ independent test showed significant hs-CRP levels difference between UAP and AMI patients $(\mathrm{p}=0.003)$ (Fiqure 2).

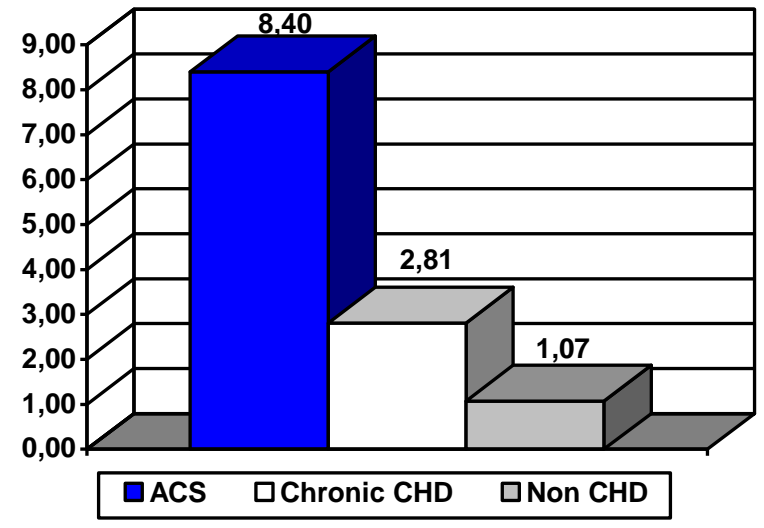

Figure 1. Comparison of mean hs-CRP levels in patients with $A C S$, Chronic CHD and Non CHD

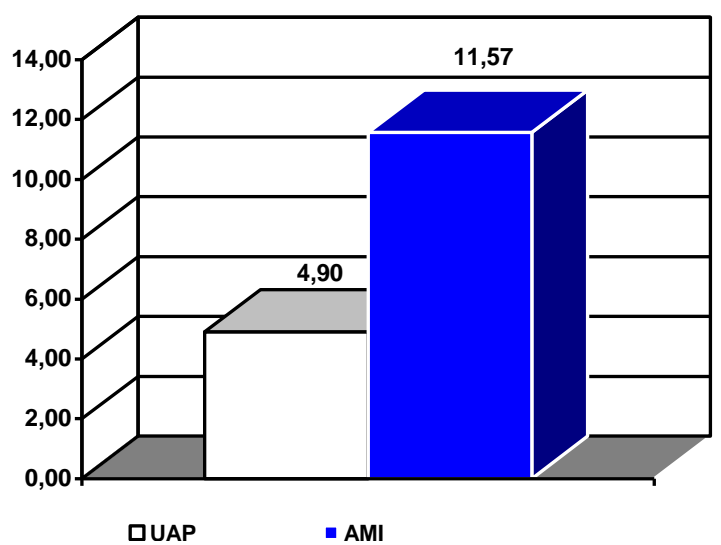

Figure 2. Comparison of mean hs-CRP levels in patients with Unstable AP and AMI

Statistical analysis result with regression analysis to find out the relationship between hs-CRP level and CKMB enzyme level in AMI patients indicated positive correlation with correlation coefficient value $r=0.783$. This result showed that the higher the CRP level, the higher the CKMB enzyme level (Fiqure 3). 


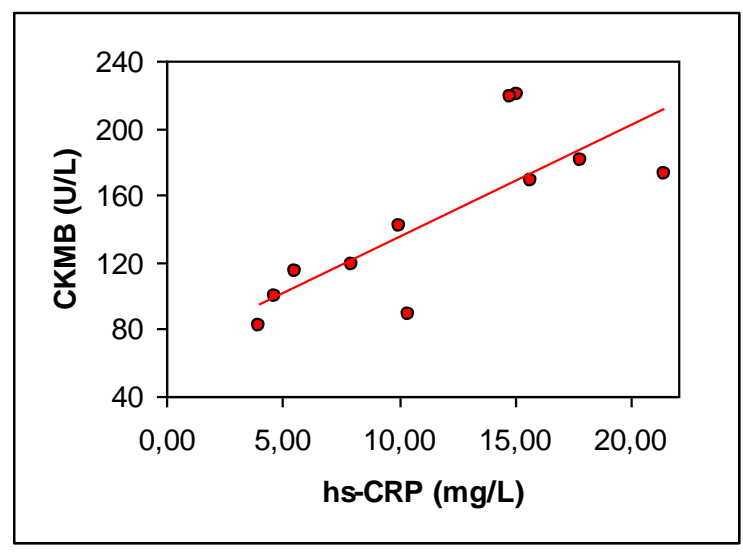

Figure 3. Correlation between hs-CRP level and CKMB enzyme level

\section{DISCUSSION}

Inflammation process in atherosclerosis can increase acute phase protein levels produced by the liver with cytokines stimulation (particularly IL-6, IL-1 and TNF- $\alpha$ ). The cytokines produced by activated macrophages, activated vessel wall cells (especially endothelial cells and smooth muscle cells) and other cells. $^{11,18,19}$ During inflammation the two most sensitive acute phase protein levels were CRP and SAA could increased, but SAA showed less significant correlation with CHD and variation result were higher than CRP. Acute phase proteins could also increase in infection and tissue damage. ${ }^{11,20}$

Age, sex, blood lipid levels and diabetes influence on hs-CRP level was not clear but obesity and smoking could increase hs-CRP levels. ${ }^{12,15}$ hs-CRP level in former smoker was the same as hs-CRP level in people who had never smoked. ${ }^{21}$ In this study, no significant difference was found in term of age, sex, BMI, hypertension, smoking, total cholesterol level, LDL and triglycerides between ACS, chronic CHD and non CHD patients but the total cholesterol level, LDL and triglycerides mean in non CHD was lower while HDL was higher.

Inflammation proved to have an important role in initiation, progression as well as atherosclerotic plaque destabilitation. ${ }^{5,12,16}$ Activated T lymphocyte cells percentage was higher in atherosclerotic lesion of UAP and AMI patients than in stable angina pectoris patients. This condition indicated that there were recent activity and immune response increase in plaque. $^{7}$ hs-CRP showed inflammation and is directly related to the extent and severity of atherosclerosis, extent of myocardial ischemia (angina) and myocardial necrosis (AMI). hs-CRP level in UAP patients was higher than in stable angina pectoris patients and hs-CRP levels in those two groups was higher than in non CHD groups. ${ }^{8,20}$

The mean hs-CRP level in chronic CHD patients in this study was 2.81 (SD 2.09) $\mathrm{mg} / \mathrm{l}$. This result was lower than the result reported by Ridker et $\mathrm{al}^{22}$ who found the mean hs-CRP level in chronic CHD patients $3.6 \mathrm{mg} / \mathrm{l}$ but higher than the one reported by Haverkate et $\mathrm{al}^{11}$ who found mean hs-CRP level 1.68 $\mathrm{mg} / \mathrm{l}$. According to Pasceri et $\mathrm{al}^{23}$ the risk of AMI in stable angina pectoris patients with hs-CRP level > $3.6 \mathrm{mg} / \mathrm{l}$ was twice as high as in patients with hs-CRP level $<3.6 \mathrm{mg} / \mathrm{l}$.

The mean hs-CRP level in non CHD in this study was 1.07 (SD 0.81) $\mathrm{mg} / \mathrm{l}$. This result was not significantly difference from that reported by Berk et $\mathrm{al}^{24}$ who found the mean hs-CRP level in non CHD $0.9 \mathrm{mg} / \mathrm{l}$. In healthy people hs-CRP level correlated with the risk of future cardiovascular events. hs-CRP levels of $<1$, 1 to 3 , and $>3 \mathrm{mg} / \mathrm{l}$ correspond to low, moderate and high risk groups for future cardiovascular events. hsCRP levels $>10 \mathrm{mg} / \mathrm{l}$ in healthy people indicated occult infection or other systemic inflammatory process so that hs-CRP examination should be carried out again one month later or after the infection was recovered. ${ }^{10,14}$

Kennon et $\mathrm{al}^{25}$ found the mean hs-CRP level in UAP patients $4.57 \mathrm{mg} / \mathrm{l}$, whereas Mach et al ${ }^{18}$ found it in UAP and AMI $5.0 \mathrm{mg} / \mathrm{l}$ and $17.0 \mathrm{mg} / \mathrm{l}$. Acording to Maseri et al ${ }^{26}$ hs-CRP level in UAP patients could be used to predict the course of the disease. hs-CRP level $>3 \mathrm{mg} / \mathrm{l}$ and in particular if $>10 \mathrm{mg} / \mathrm{l}$ can predict poor response toward intensive care and indicated high risk to AMI events.

In this study it was found that the mean hs-CRP level in UAP and AMI patients was 4.09 (SD 2.21) $\mathrm{mg} / \mathrm{l}$ and 11.57 (SD 5.78) $\mathrm{mg} / \mathrm{l}$ and statistic analysis result showed significant difference $(\mathrm{p}=0.000)$. The mean hs-CRP level in UAP patients in this study did not differ much from the above result, while the mean hsCRP level in AMI patients in this study was lower than that reported by Mach et al. ${ }^{18}$ This was probably due to interindividual variation. According to de Maat et $\mathrm{al}^{27}$ response from hs-CRP showed interindividual variation in which there were high responders and low responders patients. 
High hs-CRP level in AMI patients showed more intensive inflammation reaction that dealt with myocardial tissue damage extent (myocardial necrosis). ${ }^{20,27,28}$ de Beer et $\mathrm{al}^{9}$ reported that there was significant correlation between hs-CRP level and CKMB enzyme level in AMI patients. This was an accordance with the result of this study in which there was significant positive correlation between hs-CRP level and CKMB enzyme level in AMI patients.

\section{CONCLUSION}

hs-CRP level is consistently higher in patients with ACS compared to patients with chronic CHD and non CHD. hs-CRP level is consistently higher in patients with chronic CHD in comparison to non CHD but no statisticaly significant difference was found. hs-CRP level is consistently higher in patients with AMI in comparison to UAP patients. A positive correlation was found between the increase level of hs-CRP and CKMB enzyme level.

\section{REFERENCES}

1. Santoso T. Kemajuan kardiologi masa kini dan harapan di masa mendatang : fokus pada penyakit jantung koroner. In: Bawazier LA, Alwi I, Syam AF dkk (Eds) : Pendekatan Holistik Penyakit Kardiovaskular, Pusat Informasi dan Penerbitan Bagian Ilmu Penyakit Dalam FKUI, Jakarta, 2001, hal 1-11.

2. Ross R. Atherosclerosis - an inflammatory disease. N Eng J Med 1999;340:115-26.

3. Waters DD. Diagnosis and management of patients with unstable angina.In Fuster V, Alexander RW, O'Rourke RA et al (Eds) : Hurst's The Heart, 10 th ed, Mc GrawHill, New York, 2001, pp 1237-74.

4. Nursamsu, Kalim H. Peran autoimunitas pada patogenesis aterosklerosis. In: Setiyohadi B, Kasjmir YI (Eds) : Naskah Lengkap Temu Ilmiah Reumatologi 2002, Ikatan Reumatologi Indonesia, Jakarta, 2002, hal 1-12.

5. Suryadipraja RM. Peran inflamasi pada patogenesis aterosklerosis. In: Alwi I, Setiati S, Sudoyo AW dkk (Eds) : Naskah Lengkap Pertemuan Ilmiah Tahunan Ilmu Penyakit Dalam 2001, Pusat Informasi dan Penerbitan Bagian Ilmu Penyakit Dalam FKUI, Jakarta, 2001, hal 1-16.

6. Rackley CE. The role of plaque rupture in acute coronary syndromes. UpToDate 2001 vol 9.3.

7. Van der Wall AC, Piek JJ, de Boer OJ et al. Recent activation of the plaque immune response in coronary lesions underlying acute coronary syndromes. Heart 1998;80:14-8.

8. Liuzzo G, Biasucci LM, Gallimore JR et al. The prognostic value of $\mathrm{C}$-reactive protein and serum amyloid A protein in severe unstable angina. $\mathrm{N}$ Eng $\mathrm{J}$ Med 1994;331:417-24.
9. de Beer FC, Hind CR, Fox KM et al. Measurement of serum C-reactive protein concentration in myocardial ischaemia and infarction. Br Heart J 1982;47:239-43.

10. Yeh ETH, Willerson JT. Coming of age of C-reactive protein. Circulation 2003;107:370-2.

11. Haverkate F, Thompson SG, Pyke SDM et al. Production of C-reactive protein and risk of coronary events in stable and unstable angina. Lancet 1997;349:462-6.

12. Rifai N, Ridker PM. High-sensitivity C-reactive protein : a novel and promising marker of coronary heart disease. Clin Chem 2001;47:403-11.

13. Pearson TA, Mensah GA, Alexander RW et al. Markers of inflammation and cardiovascular disease. Circulation 2003;107:499-511.

14. Ridker PM. Clinical application of C-reactive protein for cardiovascular disease detection and prevention. Circulation 2003;107:363-9.

15. Tracy RP. C-reactive protein and cardiovascular disease. Clinical Laboratory News 1998;8:14-6.

16. Wijaya A. Faktor risiko penyakit kardiovaskuler perspektif baru. Forum diagnosticum Prodia diagnostics educational services No 2/1998, hal 1-28.

17. Ridker PM. Role of inflammation in the development of atherosclerosis. Implications for clinical medicine. Eur Heart J 2000;2 (suppl D):D57-9.

18. Mach F, Lovis C, Gaspoz JM et al. C-reactive protein as a marker for acute coronary syndromes. Eur Heart J 1997;18:1897-902.

19. Rader DJ. Inflammatory markers of coronary risk. N Eng J Med 2000;343:1179-82.

20. Wijaya A, Kurniasih R. High sensitivity C-reactive protein (hs-CRP) suatu petanda untuk menentukan risiko penyakit jantung koroner yang menjanjikan Forum diagnosticum, Prodia diagnostics educational services No 2/2001, hal 1-15.

21. Koenig W, Sund M, Frohlich M et al. C-reactive protein, a sensitive marker of inflammation, predict future risk of coronary heart disease in initially healthy middle aged men. Circulation 1999;99:237-42.

22. Ridker PM, Rifai N, Pfeffer MA et al. Long-term effects of pravastatin on plasma concentration of C-reactive protein. Circulation 1999;100:230-5.

23. Pasceri V, Willerson JT, Yeh ETH. Direct proinflammatory effect of C-reactive protein on human endothelial cells. Circulation 2000;102:2165-8.

24. Berk BC, Weintraub WS, Alexander RW. Elevation of Crective protein in "active" coronary artery disease. Am J Cardiol 1990;65:168-72.

25. Kennon S, Price CP, Path FRC et al. The effect of aspirin on C-reactive protein as a marker of risk in unstable angina. J Am Coll Cardiol 2001;37:1266-70.

26. Maseri A, Biasucci LM, Liuzzo G. Inflammation in ischaemic heart disease. BMJ 1996;312:1049-50.

27. de Maat MPM, Haverkate F, Kluft C. C-reactive protein : a cardiovascular risk factor. Fibrinolysis \& Proteolysis 1998;12:323-7.

28. Suryadipradja RM. Respon imun dan inflamasi pada penyakit jantung koroner. In: Makmum LH, Alwi I, Mansjoer A (Eds) : Pendekatan Holistik Penyakit Kardiovaskular II, Pusat Informasi dan Penerbitan Bagian Ilmu Penyakit Dalam FKUI, Jakarta, 2003, hal 53-62. 